\title{
Corrigendum: Enhancement of RNA-directed DNA methylation of a transgene by simultaneously downregulating a ROS1 ortholog using a virus vector in Nicotiana benthamiana
}

\author{
Shungo Otagaki, Megumi Kasai, Chikara Masuta and Akira Kanazawa* \\ Research Faculty of Agriculture, Hokkaido University, Sapporo, Japan
}

Keywords: Cucumber mosaic virus, DNA demethylation, RNA-directed DNA methylation, ROS1, virus-induced gene silencing

\section{OPEN ACCESS}

Edited and reviewed by:

Michael Wassenegger,

RLP AgroScience, Germany

${ }^{*}$ Correspondence:

Akira Kanazawa

kanazawa@res.agr.hokudai.ac.jp

Specialty section:

This article was submitted to

Plant Genetics and Genomics,

a section of the journal

Frontiers in Genetics

Received: 02 December 2016

Accepted: 13 January 2017

Published: 01 February 2017

Citation:

Otagaki S, Kasai M, Masuta C and Kanazawa A (2017) Corrigendum:

Enhancement of RNA-directed DNA

methylation of a transgene by

simultaneously downregulating a

ROS1 ortholog using a virus vector in

Nicotiana benthamiana.

Front. Genet. 8:5

doi: 10.3389/fgene.2017.00005

\section{A corrigendum on}

Enhancement of RNA-directed DNA methylation of a transgene by simultaneously downregulating a ROS1 ortholog using a virus vector in Nicotiana benthamiana

by Otagaki, S., Kasai, M., Masuta, C. and Kanazawa, A. (2013). Front. Genet. 4:44. doi: 10.3389/fgene.2013.00044

We have become aware that an incorrect image was mistakenly used for Figure $2 \mathrm{C}$ in the original publication. The correct version of Figure 2 is shown here. We should also note that the primers used for quantitative RT-PCR of the NbROS1 gene listed in Table A1 turned out to have a sequence mismatch with the target. The mismatched nucleotides in these primers are underlined: 5'-CCAAGAAGCTGGTAGGTTAT-3' (NbROS1 real 3' F); 5'-GCAAACACCTCGTTTAACTT$3^{\prime}$ (NbROS1 real $\left.3^{\prime} \mathrm{R}\right)$. We found that a set of primers without sequence mismatch $\left(5^{\prime}-\right.$ CCAAGAAGCTGGTAGGCTAT-3'; 5'-GCAAACACCTCGTTAACTT-3') yielded amplification products at a higher level, although both primer sets amplified a single DNA fragment and were valid for quantification, i.e., comparison of the relative level of NbROS1 mRNA between samples.

The correct Figure 2 with its legend appears below. The authors apologize for any inconvenience caused.

Conflict of Interest Statement: The authors declare that the research was conducted in the absence of any commercial or financial relationships that could be construed as a potential conflict of interest.

Copyright (๑) 2017 Otagaki, Kasai, Masuta and Kanazawa. This is an open-access article distributed under the terms of the Creative Commons Attribution License (CC BY). The use, distribution or reproduction in other forums is permitted, provided the original author(s) or licensor are credited and that the original publication in this journal is cited, in accordance with accepted academic practice. No use, distribution or reproduction is permitted which does not comply with these terms. 


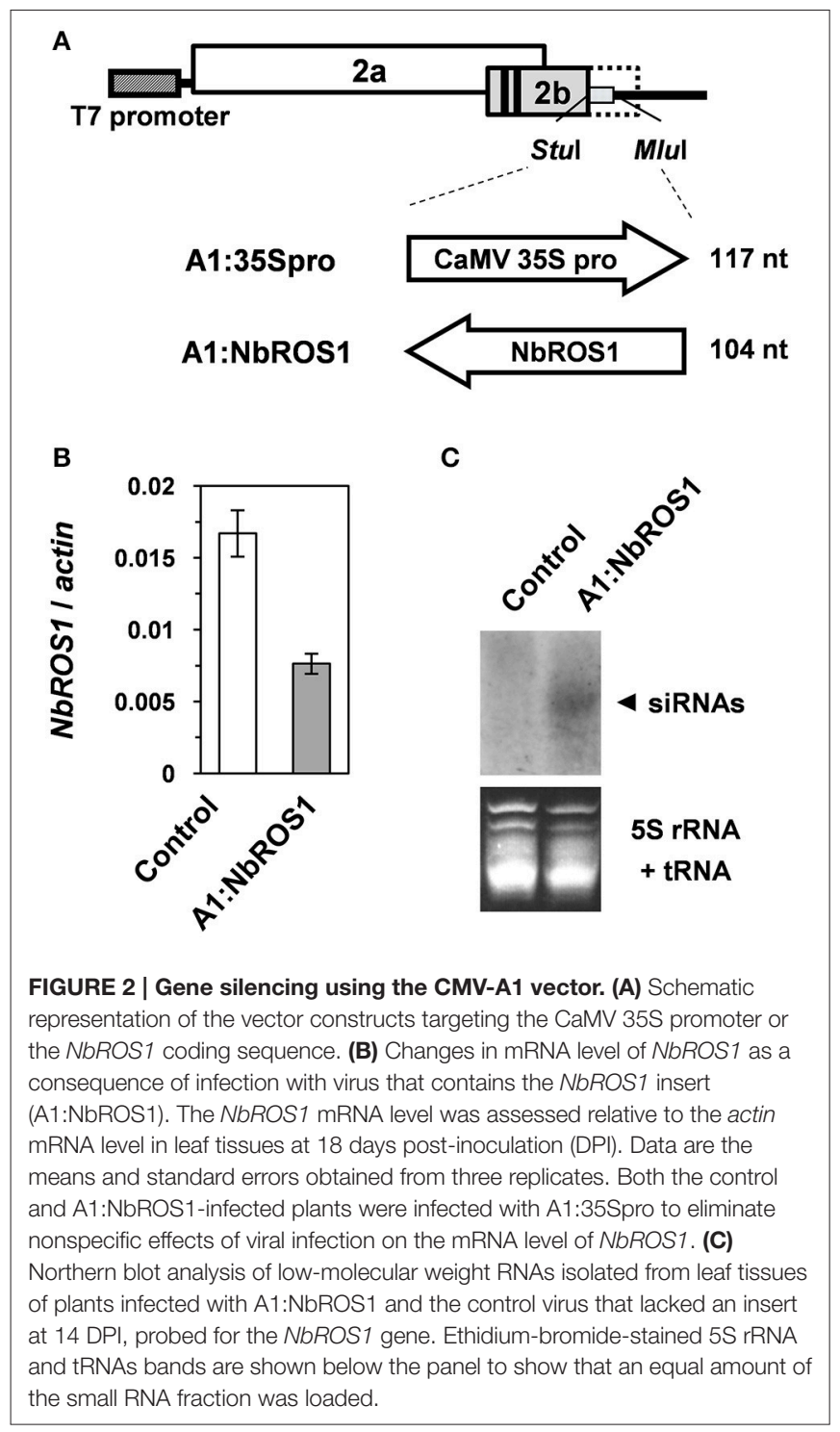

